\title{
Reference Service
}

の現場から

\section{《特別寄稿》}

五十嵐有 行*

\section{はじめに}

閲覧の係として勤務する以上閲覧者の求め んとする要求に正しく合致する資料の提供こ そ閲覽係の本命とすべきだと考光て微力の及 ぶかぎり走り趈っている。しかしぞの程度ま でそらした努力が役に立ったか自分には分ら ないが，後から扰礼を言われたりするところ を見れば当っていなかったとは思われない。 一回一回がなまの勉強になり少しづつ仕事に 自信が生れ，生来好きな事だけに增々面白さ が湧き図書館員たる事に pride をいだかせて くれた。今まで経験した事は誠に雑多である のと不勉強のためと，なおかつ，記録もろく にしていないためとで比較的大きく心を動か した事か，ごく新しい事だけしか記憶として 残っていないが，苦心した事などはいつのま にか身について，次の来館者に何らかを与兄 て行く事が出来ると思う。つたない今までの 仕事の内容を思い浮べると共に自分の抱負や 今後の行くべき方向に思いを致してみたい。

\section{利用者の立場から}

吾々は図書館を図書館の殸の中から考兵る が逆に自分を図書館を利用する学生なり職員 の立場汇置き換えてみれば，どんな態勢が望 ましいかがわかる。自分の学生時代を振りか えってみる。図書館とは何をする場所と考兄 てのぞんだか，どれだけの信頼感を抱いた か，係の人はあれでよいものと思ったか等々 回想してみるとき，図書館は格別に魅力のあ る場所ではなく，ただ手許に読みたい本が手 に入らないとき仕方なしに行く場所で，何も

\footnotetext{
* Ariyuki IGARASHI 金沢大学医学因書館
}

わざわざ面倒な手続きをしてまで借出したり するに当らないといらよらな頼りない気持が 先にたったようだ。これは自分が不勉強だっ たし，またずっと昔の事だから現在と異なる のは当然であるが，学生時代に内在した図書 館に対する安易な気持が，今も完全に払拭さ れているとは思われない。何かこんな気持が 底流にあると思う。何のためか？研究者は 勿論学生も大学人である。殊に医学部に於い てはインターンがすみ, 学士試験が終りさえ すればれっきとした先生になる訳で，最初か らエリート意識が強いから専門の資料を果し て自分のために図書館人が提供出来るかどう かに疑念を抱くのは当然である。このような 気持が閲覽者と図書館人が最初から気楽に話 し合うための壁となっているのが，原因の一 つと思う。利用者は鬼角すると図書館は研究 資料を保管してある場所く蔵〉といった昔風 の考方方に和ち入りやすいから，求められた 資料を充分隹調査する事なく謝絶するような 事があったなら増々図書館と遊離する。軽い 気持で図書館に来る閲覧者が少ないのは両者 の最初の壁が完全に取り払われないためであ ろら。こんな事情もあることだから，reference librarian としては少しでも要求に合。 た資料を早く提供するために妢力するのを最 初の目標とし，来館者の気持を忖度し少くと も一度でも来た人にいやな後味を抱かせない ための努力がいる。

\section{利用者別のサービスを}

閲覧は来館者の層によって求める内容もま た利用の方法，目的も異なるから大別して次 
のように考えてみる。

A）学内事務系の人, 他の学部の人, 学外好 事者, B) 学生, C) 教官, 研究員, 大学院 学生。本学の場合 A) は人数も少ないし求め る要件も研究のためとは離れたよらな事が多 い。本学と関係のある特定の人の生年月日, 履歴，論文の標題，著書などはまだ調べられ るが，人となりなど求められる時は昔一緒に 仕事をした人とか本学に長く勤務している人 などを紹介する外ない。その他本学の歴史的 記録, 新しい化学機器の用途なども尋ねられ る。一度大正時代皇太子殿下が行啓された時 の記録など求められた事があったが新聞の縮 刷版があって事足りた。学外の好事者は医学 書を求めるに違いないが，自分に関心のある 方向の事をまとめた新しい図書でもあれば喜 ばれる。次に B）の学生の場合も主として 単行書であるが利用しに来る時は矢張り試験 のためが多い。Text bookなら全部ではない にしても一応自分で持っているが，試験の問 題は現代医学の新しい課題となっている部分

（すなわち text book ではその他と書いた部 分にあって二三行しかふれてないところ，こ の事についてはな怙不明な点が多い，諸説が あるなどぼやかした表現がもちいられるとこ ろ）一を対象としていることが多く，さらに 基礎の場合に臨床との関連, 臨床の場合には 基礎と組合っていることが多い。だから質問 する人自身どんな方向の本を見たら求める事 が一番よく書いてあるか，わからないことが 多い。胸腺の腫瘍の病理を内分泌といってさ がしたりするたぐいである。そのため求める 対象が見当はずれになって聞えたりする。 “血漿蛋白”とだけ言われたりした時すぐそ のままに受けとらず総説的に書いたものか, 血液凝固との関係, 免疫との関係, 化学組成, 輸血, 分画法, 特定疾患における成分の増減 など関連する箇所をあげてどの部類に属する かをはっきり言ってもらら。ここを正確につ
かななとどの本がよいか分らない。昨年, 膠原病について病理の試験があった時, 学生 は病理のテキストにふれるところが少いため collagen disease なる title の本を求めたがっ た。Title にその通りの名前の出た本は二冊 ぐらいしかなったが 5 人も 6 人も皆同様の注 文のため，たちどころに借り出され後から来 た連中は適当な本がないと不満そらだった。 閲覧室の棚に何冊も利用出来る本があるのに 題名が膠原病とか collagen disease とか書い てないとすぐ間に合わないように思う。それ で "Inflammation and diseases of connective tissue”とかリウマチ, リウマチ新説, “Practice of allergy”臨床アレルギー, 皮フ病理 学強皮症などの本を出して利用してもらっ た。これらの本の中には膠原病の全般につい てはふれていないものもあったが，かなり役 に立った。同一の方向の本に違いないが，主 題が多岐にわたる場合同一個所にも置かれな いため平常吾々が心していないとよい本もも らいられない。一時新聞で話題をよんでいた “Rh-”血液型にしても，始めから輸血か血 液型の本を探して，思らように書いてないと 困ったよらにみえる人があった。くわしく関 連領域にあたる血液学, 遺伝, 血清学, 法 医，救急療法，大きな外科の手術書など考え て探せばよいのにつっこんで探そうとしな い。本棚の前で当惑した様子にみ只る人や， やたらに本ばかり引出しているよらな人のあ った時は，ただちに近よって何を求めている かを聞き，その人と同じ事を自分が調心゙る気 持で探がす。自分は別に医学を学んだもので はないから失敗をいとわず臆せずにこれなら 役に立つと思ら資料を提出し，いけない時は それについての批評を聞き，不分明だったら 問い直して更に合ったものを求めることにし ている。特別新らしい topic のよらな事とか 地域的にでも限られた事, 社会医学に関連の ある隣接科学の問題などはともかく, なにか 
参考になる事は得られるものであるから，そ の時わからねば，学年，名前などを聞いてお いて資料が得られたらその時連絡する。

\section{PR とオリエンテーション}

利用図書の検索選択のためには目録の重要 性を無視してはならないが，いかに精巧な目 録が作られたとしても資料の検索のための一 つの手続であり図書館員の仕事を手伝ってく れるものに過ぎない。だから閲覧者の利用の 仕方如何で可とも不可ともなりかねない。殊 に学生は目録カードを落着いて調べたりしな いから馴れるように誘導するのも大切だが,

図書館に親近感を充分にもって，何でも気軽 に相談しかけてくれる風潮に持ち込むのが先 決だと思う。眓書館に来る回数さえ多くなれ 价自づと目録の使い方にも馴れてくる。眓書 館員は出来るだけ閲覧者の気持を理解し更に 手となり足となって協力するだけの心構えを 持って仕事につきあたらないと, 図書館自体 の不評となってはねかえるのである。閲覧者 は自己の勉学のプラスになるものさえあれば いくらでもまだまだ吸収する。その材料を蔵 しながら提供するのを意っては図書館の洒值 は減殺される。ここにサービスがなりたち， これがなければ図書館はあり得ない。自分の みるところでは毎日日課のようにして図書館 に足を運ぶ人の数は少ない。インターンの間 も含めて 5 力年間の学生生活中に一回も姿を 見ない人さえあるのではなかろらか。之に対 し入学早々から来た人は後に教室で研究する ようになっても, 調べたい事があれば直ちに 来て何でもたずねてくれる。こらして考えて みるとき，施設の近代化による快適な環境が 整備されていないこと, $\mathrm{PR}$ 活動の不足もさ ることながら，オリエンテーションによる図 書館認識の深まるのを期待したい。要するに 学生に対してはその心中の pride 感を充分察 知しながら勉学意欲をもりあげるように補導 し, 先方がとまどっている様子をみたら求め
るところを聞き資料を検索, 提供し, 気楽に話 し合えるように相互のへだてを取り除くため に努力する。

C）の教官や大学院学生を含む研究員は, もら先生だから一応自分の所属の教室とむす びついた一次資料の利用が主となってくる。 それだけに求められる事もずっと複雑化す る。研究のはじまる当初は Annual review やAdvance のような新しい研究の動向をさ ぐるようなものから手がかりが求められる。 この時分は雑誌の名前も充分知らず, original な文献の多い本か，abstract が大部分になる 本か, 発行回数その他も知らない人が多く, 唯 reference に挙げてあるとろを列記するた め, 論文の題ばかり書いて誌名その他肝じん のところを書き捛とす例まであった。こんな 時には解説をしたり今後のために tool の使 用について実地にみてあげることにしてい る。しかしいつも来館する人の中にも二次文 献について充分知らないためか，直接的に自 己の研究と関係の少い部分について調べねば ならないことが起ったときなど，新しい図書 や雑誌から関連のあるものを見つけてほしい などいわれる。ハシカワクチンの副作用とし て頭に影響のある例を求められたが Index Medicus の新着の分からさかのぼって vaccinationを key word に検索した。先日も糖 尿病の全般にふれた図書を出して見せて欲し いといわれた。病理の先生だからかえって内 科学大系のような臨床の本がよいかと思って 見せたら古すぎるといわれた。それでどんな 種類の糖尿病かを陦ねたとき, “Heart disease in infancy and childhood”なる本を手にさ れたので病院から迴った材料が糖尿病で先天 性心臓奇形だったのでないかと思い, “Congenital heart disease" $と$ “Congenital malformations of the heart” の二冊と雑誌糖尿 病の二冊を出してこと足りた。このような場 合研究者にすればゆっくりカードなど引く時 
間もないのかもしれないが，求めんとすると ころをはっきり教えて欲しい。

今までのところ Chrolophyl の栄養につい てドイッ文献を本学所蔵の雑誌の中から求め られ “Index Catalogue of the Library of the Surgeon-General's Office”より索出した程 度で retrospective search といってよいよう なことは殆んど数がないが，今後このような 依頼の出た時は医学は二次資料として立派な ものがあるだけにフルに活用して役に立てた い。そのためにも $\mathrm{MeSH}$ の二力所三力所で 重なる key word など,どこの分野でぞら結 び合うか解明したい。今研究者から求められ るのは期限付で調査しなければならない時と か，めずらしい患者があった時とか，剖検し

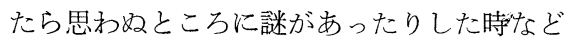
の文献であり，この場合文献の数よりも何か 手がかりを早く手に入れたいようにみえる。 研究者の求めるのも雑誌ばかりではない。先 年腎血管性高血圧の本を求められたが，hypertension の国際学会の proceedings にも見 当らないので困ったけれども，数力月たって 英語の単行書が発売されたのを知り知らせて あげた。また $6 ， 7$ 年前だったが，富山県の 神通川流域に発生する地方病“いたいいたい 病”について探したことがあったが，最初骨 軟化症についての栄養的見地から書いたもの という話だったが，この地方病の病源につい ての研究とわかり “臨床栄養” “日本農村医 学会誌” “労働の科学” 昔の “十全会雑誌”, 更に明治時代の婦人科医によって書かれた “富山県奇病論”富山県警察部の調査書など 古い書物を引出して, 従来不明とされたとこ ろを調べてもらった。

しかし調查は一つの主題について長期的に 新着雑誌から検索するのと異なり，その時そ の時の閲覧者の意図に応ずることとなる。完 全な文献の screening などは依頼もないため 手がけていない。しかし新着雑誌を展示して
いて特に目につき，これはあの先生が求めて いたなどと気のつくものはメモして知らせ る。I M, Excerpta Medica, Current Contents などにやがてのるには違いないがつづけて記 録して行きたい。こうしたことのために professor の研究の方向と各教室がどんなグルー プに分れてやっているかを把握するように努 める。これと借用文献の title を考え合せれ ばその人がぞんなグループに属するか判明 する。勿論多くの研究者しかも年々交代する 人々を全部知ることは出来ないが，接する機 会の多い人については大体手にされる誌名は 見当がつく。こういったことも reference service に直結することだと思う。

\section{医学の動向の正しい把握を}

以上閲覧者を分けて吾々の対するところを 書いてみたがどの場合についても考えねばな らないのは医学の動向を正しく catch する ために努力することである。新聞に一寸載っ た記事にも進歩して止ま学問の片鱗がうか がえる。昔は癌の基礎的な研究にしても病理 学の上から主として考えられた。だが癌が実 験的に作られ，発癌因子の追求となると生化 学の上からの研究が欠かせなくなった。そし て化学とともに制癌剤の研究となり，その発 生を, 生物理学的に化学物資によるDNA 分 子内の電荷の移動の面から，またウィルス一 バクテリオフアージの遺伝, アゾ色素, ホル モンの果す役割，放射能の影響などから研究 されるよらになって来た。一方病理の方も網 内系などの研究は超ミク口の世界に進み, 電 子顕微鏡の出現に警く間もなく，放射線を利 用して更に更に拡大し, 現実の細胞の立体像 をとらえんとしている。いうなれば癌の基礎 の研究といっても病理細胞学, 生化学, 生物 理学, ウィルス学, 生物放射線, 遺伝学, 内 分泌学等々が分子生物学的な考え方と結びつ いて研究されている。こうしたことは癌の発 生などという今の医学の頂点に立つような部 
門のみに限らず，すべての分野で起ってい る。それで研究が進めば進む汪ど頂点をめざ す研究は多角化し, 複雑化して一昔前に考兄 ていた方向のみでは一角のみを見つめている こととなり，全容の把握が出来ない破目に陥 る。それでは利用者から求められることの見 当がつかない。従って吾々の reference はい つでも研究の進歩とともに動くものであるこ とを銘記して医学の最近の進歩を見つめなけ ればならない。

次に医学の特殊性を考えねばならない。吾 々に与えられる質問が変化し多角化するのは 医学の進歩に結びつくが，この複雑化を他の 科学と較べるとき，゙っと高度なのではなか ろらか。実際人は一寸した風邪にも全身に苦 痛を括湆える病気一異常は全身につながる人 間といら生体の異常状態を究明して正常な状 態へ導く方法を求める科学だけに, 研究にも この通りのことが現われる。なるほど各科に 分れて研究されているが，各々のグレンツゲ ビートは重なり合う面が多く, 時にはいくつ ものその重なる面をつらねて新しい学問体系 が成立し複雑化がはげしくなる。どんな科の どんなことも別の科とつながる。人間の科学 であれば当然かもしれない。これは医学が applied science であるがための宿命であろ ら。基礎の教室で卒業後10年もこの道に努力 していたある先生がもらされた言葉だが,「ど らしても医学は分らない。系統を整然とさせ ることが出来ない。これでまとまるかと思ら と, 他の科学の研究が障壁となりつまづく。 自分のやっているのは医学の中では一番筋道 の通った学問だと思らが，ここでさ光数学や 物理学のように系統のたった考方方がとれな い。いつでも中間で別の事とぶつかる。」つ まり医学は応用科学で別の科学の進歩発達 とらえて人体研究に応用するものだから，は じめの科学では正しいとされる事も複雑な生 体機能に於いては，その ruleを通すと無理
が起ることがあるのであろら。血液の化学な ぞの実験研究には化学者の考えと異なるとこ ろが多いときく。こうして他の科学の進歩は 宿命的に医学研究に難問を持ちかけて医学の 進歩を助長する。医学では, 一部に他の科学 が導入されて成果をあげたとき，たちどころ に拡がりぞことでも結び合ら。これは化学, 物理, ェレクトロニクス, ウィルス， R. I, 統計学などの実情を見ても明らかである。こ れが医学の複雑さの大きな原因だと考光る。 勿論他の科学にも同様な事があるに違いない がこれ程の事はないと思う。それで reference にあたるものは, 自然科学, 社会科学の系列 と較べ合せて考え，どんな質問のあったとき でも先ずどの系統と結びつくかを判断する事 が必要だと考える。

\section{おわりに}

以上で本学の reference の実情とそのため に必要と考光られる医学の認識について述べ たが，最後は今後に処する librarian の心構 えに触れて稿を了えたい。

図書館の窮極の目的は, 利用者への service に尽さる。その service の最先端に立つのが 閲覧・参考係である。その仕事が兔角すると 図書館の中で軽視されがちになる。実際どれ だけよくやっても利用者は当然のこととして みるのがあたりまえで，逆にわるくやると図 書館の空口であるだけに，館全体の不評とな って返ってくる。今後の図書館の発展に思い を至すとき，一番図書館の目的に合致するの がこの仕事だと考え， reference にあたるす のは常に研鑽に努めて, 利用者の要求に正し く合致した service を提供すべきである。こ の気持が館全体にわき上らねば図書館の向上 は望めない。如何に立派な機械も操作するの は人間である。大学の使命と直結する仕事の 重大性を勘案して, 自らの仕事の責任をいだ く心の持ち方が肝要であると思う。 